JOTE Volume 2 Nomor 1 Tahun 2020 Halaman 231-238 JOURNAL ON TEACHER EDUCATION

Research \& Learning in Faculty of Education

\title{
PENINGKATAN KEMAMPUAN MEMBACA PERMULAAN MENGGUNAKAN METODE STRUKTUR ANALISIS SINTESIS (SAS) DI SEKOLAH DASAR
}

\author{
Nelpita Sari ${ }^{1}$, Musnar indra Daulay ${ }^{2}$, Nurhaswinda ${ }^{3}$ \\ SI PG-SD, Fakultas IImu Pendidikan, Universitas Pahlawan Tuanku Tambusai \\ nelvitasari97uptt@gmail.com
}

\begin{abstract}
Abstrak
Penelitian ini bertujuan untuk mendeskripsikan peningkatan hasil belajar Bahasa Indonesia materi membaca permulaan. Metode ini adalah Penelitian Tindakan Kelas (PTK) yang dilaksanakan dalam dua siklus. Setiap siklus terdiri dari dua pertemuan dan empat tahap, yaitu perencanaan, pelaksanaan, observasi, refleksi. dan waktu penelitian dilaksanakan mulai bulan September hingga Oktober 2020. Subjek penelitian ini siswa kelas II yang berjumlah 14 orang siswa. Teknik pengumpuan data berupa wawancara, dokumentasi, observasi dan tes. Hasil penelitian ini dapat disimpulkan bahwa hasil belajar siswa materi membaca permulaan kelas II SDN 016 Kemang Indah pada siklus I dan siklus II menunjukkan diantaranya sebelum dilakukan tindakan rata-rata siswa 59,0. Pada siklus I rata-rata siswa meningkat menjadi 66,8 . Pada siklus II rata-rata siswa semakin meningkat menjadi 7,14. Dari hasil ini menunjukkan bahwa pembelajaran menggunakan metode struktur analisis sintesis (SAS) dikatakan meningkat.
\end{abstract}

Kata kunci: Membaca Permulaan, Metode Struktur Analisis Sintesis

\begin{abstract}
This study aims to describe the improvement of learning outcomes in Indonesian in introductory reading material. This method is a Classroom Action Research (CAR) which is carried out in two cycles. Each cycle consists of two meetings and four stages, namely planning, implementing, observing, reflecting. and the time of the research was carried out from September to October 2020. The subjects of this study were class II students totaling 14 students. Data collection techniques in the form of interviews, documentation, observation and tests. The results of this study can be concluded that the learning outcomes of students learning materials for reading the beginning of class II SDN 016 Kemang Indah in the first cycle and the second cycle showed that before the action was taken the average student was 59.0. In the first cycle the students' average increased to 66.8. In the second cycle the average student increased to 7.14. From these results indicate that learning using the structural analysis synthesis (SAS) method is said to increase.
\end{abstract}

Keywords: Reading Beginning, Synthesis Analysis Structural Method 


\section{PENDAHULUAN}

Membaca permulaan merupakan tahap awal dalam belajar membaca yang difokuskan kepada mengenal simbol-simbol atau tanda-tanda yang berkaitan dengan huruf-huruf sehingga menjadi pondasi agar anak dapat melanjutkan ketahap membaca permulaan (Darwadi 2002). Menurut Steinberg (Ahmad Susanto, 2011:83) membaca permulaan adalah membaca yang diajarkan secara terprogram kepada anak prasekolah. Program ini merupakan perhatian pada perkataan-perkataan utuh, bermakna dalam konteks pribadi anak-anak dan bahan-bahan yang diberikan melalui permainan dan kegiatan yang menarik sebagai perantaran pembelajaran.

Tahap membaca permulaan dititikberatkan pada kesesuaian antara tulisan dan bunyi yang ada, kelancaran dan kejelasan suara, pemahaman isi atau makna. Persiapan membaca didukung dengan pengalaman keaksaraan seperti membaca buku atau sering menggunakan tulisan maupun symbol saat pembelajaran. Bahan-bahan untuk membaca permulaan harus sesuai dengan bahasa dan pengalaman anak. Tahapan membaca anak usia dini menurut Abdurrahman M (2002:201) ada pada tahap kesiapan membaca dan membaca permulaan, adapun ciri-cirinya yaitu anak sudah mulai memusatkan perhatiaanya pada satu atau dua aspek dari sebuah kata, seperti huruf pertama yang ada pada sebuah kata dan gambarnya. Anak juga akan mempelajari kosa kata dan dalam waktu yang bersamaan anak belajar membaca dan menuliskan kosa kata tersebut.

Dari penjelasan diatas, jangan merasa bosan untuk membaca buku, majalah maupun koran. Dikelas satu siswa mulai diajari dengan mengenal huruf, yang akhirnya bisa mengenal dan membaca huruf, kata bahkan kalimat.

Dalam mencapai hal tersebut, tentunya banyak masalah yang akan muncul baik dari guru maupun dari siswa. Permasalahan tersebut diantaranya: 1. Guru masih menggunakan alat seadanya (papan tulis, spidol dan buku). 2. Siswa belum mampu dalam pengucapan bunyi tulisan dengan benar. 3. Siswa masih belum tepat dalam menggunakan intonasi dalam membaca. 4. Siswa masih belum lancar dalam membaca. 5 . Siswa masih belum jelas dalam mengucapkan kata dan kalimat. Karena kurang memadai mengakibatkan siswa kurang aktif dalam belajar, kekeributan membuat proses belajar-mengajar kurang optimal, membuat siswa jalan kemana-mana mengganggu teman dan senang bercerita dengan teman sebelah. Sehingga dapat mengganggu siswa yang memperhatikan dan mendengar penjelasan dari guru.

Tahapan pengenalan huruf akan ditemui oleh semua siswa di kelas satu/kelas awal, selanjutnya dilanjutkan ke suku kata, kata dan kalimat. Membaca sangat penting bagi semua manusia/masyarakat karna dengan membaca banyak ilmu dan pengetahuan yang akan diperoleh/didapat. Jangan mau mengalami buta huruf, jadikanlah membaca sebagai hobi/kegemaran. IImu tidak hanya didapat dengan mendengar penjelasan guru/orang lain, dengan gemar membaca banyak pula ilmu yang didapat karna buku adalah gudang ilmu. Mengganti atau melakukan pembaharuan dalam proses belajar mengajar dapat merubah suasana belajar, dari yang awalnya ribut menjadi nyaman dan tenang. 
Tentunya guru juga harus bisa menarik perhatian siswa agar proses belajar mengajar sesuai dengan yang diharapkan. Mengganti cara proses belajar mengajar dengan menggunakan bantuan media, pendekatan, metode dan lainlain sebagai pembantu dalam pemahaman siswa yang belum paham yang diharapkan dapat merubah atau membuat suasana baru dalam proses belajar mengajar. Melalui hal tersebut siswa tidak terlalu menoton memperhatikan guru dalam proses belajar mengajar seperti halnya menggunakan metode ceramah. Dalam penelitian ini peneliti menggunakan metode struktur analisis sintesis (SAS) dalam pelaksanaan penelitiannya di kelas II SD Negeri 016 Kemang Indah.

Metode SAS merupakan salah satu jenis metode yang digunakan dalam proses pembelajaran MMP (membaca menulis permulaan) bagi siswa pemula. Menurut Broto metode SAS adalah metode yang khusus disediakan untuk belajar membaca dan menulis permulaan di kelas permulaan SD/MI. Solchan dkk (2010 : 6.22) menyatakan bahwa pembelajaran membaca dan menulis permulaan dengan metode ini mengawali pelajarannya dengan menampilkan dan memperkenalkan sebuah kalimat utuh. Metode SAS adalah metode pembelajaran membaca yang dimulai dengan langkah bercerita sambil menunjukkan gambar pendukung. Setelah itu siswa diajak untuk membaca gambar tersebut, yang dilanjutkan dengan membaca kalimat yang ada dibawah gambar. Selanjutnya gambar dilepas atau diambil dan tinggallah kalimatnya. Siswa berlatih membaca kalimat tanpa bantuan gambar (proses struktural). Kalimat tersebut lalu dianalisis menjadi kata, suku kata, huruf-huruf (proses analitik). Langkah terakhir adalah menggabungkan kembali huruf-huruf menjadi suku kata, suku kata menjadi kata dan kata-kata menjadi kalimat (proses sintetik).

Pembelajaran membaca permulaan menggunakan metode SAS sangat cocok digunakan dalam pembelajaran membaca permulaan untuk siswa pemula, karena metode SAS merupakan salah satu jenis metode yang biasa digunakan dalam proses pembelajaran MMP (membaca menulis permulaan) bagi siswa pemula, pembelajaran MMP dengan metode ini mengawali pembelajarannya dengan menampilkan dan memperkenalkan sebuah kalimat yang utuh. Metode ini dalam pembelajaran menggunakan gambar, kata, huruf serta kalimat. Sehingga sangat menunjang pemahaman bagi siswa, bila siswa belum bisa membaca kalimat namun siswa telah mengetahui gambar yang ditempelkan di papan tulis, guru mulai memperkenalkan kata dengan mengajarkan huruf perhuruf hingga membentuk sebuah kalimat yang tertulis dibawah gambar.

Berdasarkan permasalahan diatas maka peneliti mengambil kesimpulan untuk mengadakan penelitian yang berjudul "Peningkatan Kemampuan Membaca Permulaan Menggunakan Metode (SAS) Pada Siswa Kelas II Di SD Negeri 016 Kemang Indah.

\section{METODE}

Penelitian ini akan dilaksanakan di SD Negeri 016 Kemang Indah yang merupakan salah satu instansi Sekolah Dasar yang menerapkan Kurikulum 2013. Lokasi sekolah ini terletak di Desa Kemang Indah, Kecamatan Tambang, 
Kabupaten Kampar. Subjek penelitian ini adalah siswa kelas II SD Negeri 016 Kemang Indah, Kabupaten Kampar, yang berjumlah 14 siswa, yakni 8 siswa lakilaki dan 6 siswa perempuan.

Jenis penelitian ini adalah menggunakan penelitian tindakan kelas (PTK). Penelitian tindakan kelas merupakan penelitian yang dilakukan oleh guru yang subjeknya seluruh siswa didalam kelas tersebut dengan tujuan untuk memperbaiki atau meningkatkan proses pembelajaraan (Marta, R, 2018:82). Penelitian dilakukan dengan jalan merancang, melaksanakan dan merefleksikan tindakan secara kolaboratif dan partisipatif yang bertujuan untuk memperbaiki proses pembelajaran di kelas melalui suatu tindakan dalam suatu siklus (Fadhilaturrahmi, 2017).

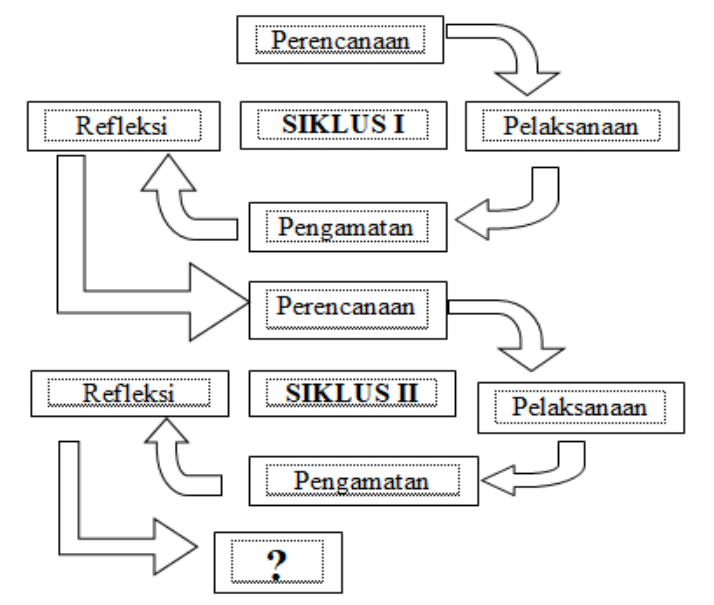

\section{Siklus Penelitian Tindakan Kelas (PTK) (Arikunto, 2010:12)}

\section{PEMBAHASAN}

\section{Pratindakan}

Sebelum dilakukan penelitian, peneliti melakukan studi awal dalam permasalahan pembelajaran yang dilakukan dengan wawancara dan observasi. Berdasarkan hasil observasi ditemukan suatu permasalahan dan pembelajaran Bahasa Indonesia khususnya dalam membaca permulaan yang terjadi di kelas II.

Hasil pengamatan peneliti pada hari Sabtu, 26 September 2020 ketika guru memberikan pelajaran Bahasa Indonesia dengan materi membaca permulaan yaitu guru mengajak siswa mengucapkan bunyi bahasa yang meliputi huruf vokal, konsonan dan diftong yaitu bunyi vokal rangkap yang tergolong dalam satu suku kata contoh ai dalam kata merangkai danau dalam kata harimau serta gabungan konsonan (ny,ng,kh). Guru mengajak siswa memberi nada tinggi rendah suatu kalimat. Guru mengajak siswa memahami suatu kalimat, kata serta menyimak saat siswa lain mengucapkan kalimat dan kata melalui kegiatan membaca nyaring. Serta memberi kejelasan dalam membaca.

Berdasarkan kegiatan tersebut, hanya beberapa siswa yang benar-benar mengikuti pelajaran meskipun guru telah melakukan pengulangan pelajaran karena siswa tidak fokus lagi dalam belajar, dan merasa terbebani saat guru menyuruh siswa mendengarkan pelajaran dan disuruh membaca kata dan 
kalimat yang sudah dibahas, dan beberapa siswa kembali lagi untuk mencari kesibukan lain dan ada juga siswa yang mencorek buku dan membuat gambar. Tanpa memperhatikan penjelasan dari guru.

Berdasarkan hasil pengamatan peneliti terhadap proses pembelajaran, dapat diketahui bahwa rendahnya kemampuan membaca permulaan siswa disebabkan beberapa faktor yaitu siswa masih belum mampu dan kurang fokus dalam belajar mengajar serta kesulitan untuk memahami pelajaran yang sudah dibahas.

Penilaian terhadap kemampuan membaca permulaan pratindakan dilakukan dengan menggunakan pedoman penilaian membaca permulaan yang meliputi 4 aspek yaitu, (1) lafal, (2) intonasi, (3) kelancaran, dan (4) kejelasan.

Keterampilan awal membaca permulaan siswa diketahui dari hasil tes membaca permulaan pada pratindakan. Hasil tes dinilai menggunakan pedoman penilaian membaca permulaan yang sudah disusun peneliti. Berdasarkan hasil tes membaca permulaan pratindakan, dapat diketahui nilai rata-rata yang diperoleh siswa belum sesuai dengan harapan.

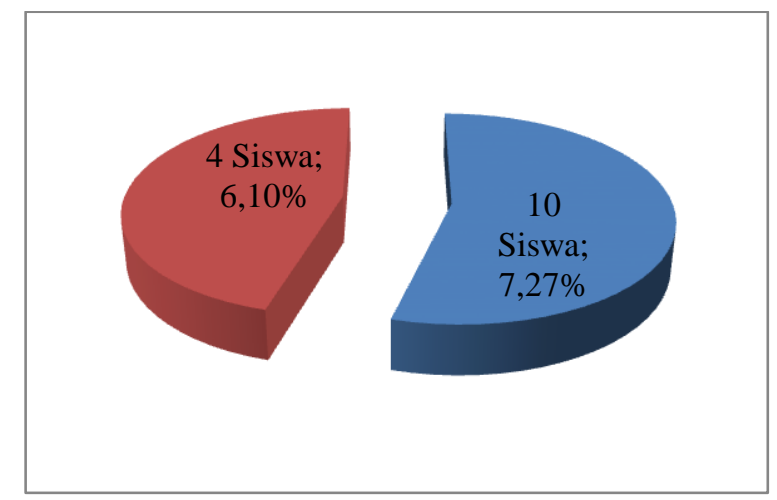

Gambar 4.4

\section{Persentase Hasil Penilaian Siswa Kemampuan Membaca Permulaan} Pada Pratindakan

Hasil belajar siswa kelas II SD Negeri 016 Kemang Indah pada sebelum tindakan masih tergolong rendah hal itu terlihat dari nilai rata-rata siswa secara keseluruhan baru mencapai 59,0. Nilai rata-rata tersebut masih berada dibawah Kriteria Ketuntasan Minimal yaitu 70. Jumlah siswa yang mencapai ketuntasan belajar juga hanya mencapai 4 siswa yaitu 7,25\%. Ketuntasan belajar siswa ini masih belum sesuai dengan kriteria keberhasilan penelitian yaitu $70 \%$.

\section{Siklus I}

Perencanaan tindakan siklus I disusun peneliti bersama guru kelas II sebagai observer, Ibuk Ariati Perencanaan disusun dengan tujuan untuk mempersiapkan segala sesuatu yang akan dilakukan dalam pelaksanaan tindakan siklus I yang bertujuan untuk meningkatkan kemampuan membaca permulaan. Kegiatan yang dilaksanakan peneliti dan guru kelas II sebagai observer pada tahap perencanaan ini yaitu:

1) Perangkat pembelajaran terdiri dari silabus, rencana pelaksanaan pembelajaran (RPP), media kartu kata dan kalimat metode struktur analisis sintesis (SAS) bergambar, lembar huruf vokal, konsonan dan diftong yang telah disusun untuk pertemuan 1 siklus I. 
2) Meminta kesediaan guru kelas II yaitu Ibuk Ariati untuk menjadi observer aktivitas guru (peneliti), teman sejawat yaitu Sri Sanita untuk menjadi observer aktivitas siswa.

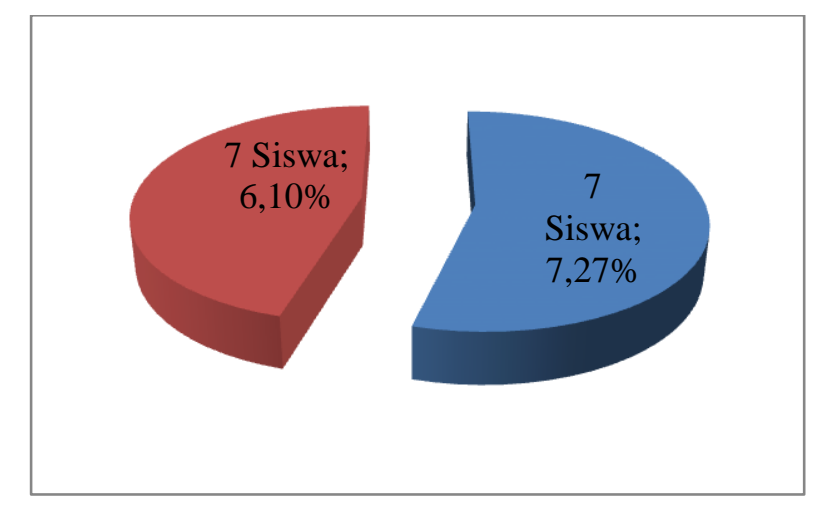

Gambar 4.9

Presentase Hasil Penilaian Siswa Kemampuan Membaca Permulaan Pada Siklus I

Hasil tes tindakan siklus I setelah diterapkan belajar menggunakan metode Struktur Analisis Sintesis hasil belajar siswa mengalami peningkatan dari 4 siswa menjadi 7 siswa atau $7,27 \%$ sudah tuntas belajar dan masih ada 7 siswa atau $6,1 \%$ siswa yang belum tuntas belajar. Perolehan skor ratarata mengalami peningkatan sebesar 66,8 (kondisi awal 59,0 meningkat menjadi 66,8 ). Skor ratarata setiap aspek dalam penilaian juga mengalami peningkatan.

Berdasarkan hasil tes tindakan siklus I dinyatakan bahwa proses belajar siswa sudah mengalami peningkatan, namun meskipun meningkat tetapi nilai rata-rata siswa masih berada di bawah KKM 70. Sebab itu, peneliti berdiskusi dengan guru kelas yang menghasilkan bahwa diadakan tindakan siklus II untuk meningkatkan hasil belajar siswa yang masih di bawah KKM.

\section{Siklus II}

Perencanaan tindakan siklus I disusun peneliti bersama guru kelas II sebagai observer, Ibuk Ariati Perencanaan disusun dengan tujuan untuk mempersiapkan segala sesuatu yang akan dilakukan dalam pelaksanaan tindakan siklus I yang bertujuan untuk meningkatkan kemampuan membaca permulaan. Kegiatan yang dilaksanakan peneliti dan guru kelas II sebagai observer pada tahap perencanaan ini yaitu:

1) Perangkat pembelajaran terdiri dari silabus, rencana pelaksanaan pembelajaran (RPP), media kartu kata dan kalimat metode struktur analisis sintesis (SAS) bergambar, lembar huruf vokal, konsonan dan diftong yang telah disusun untuk pertemuan 1 siklus I.

2) Meminta kesediaan guru kelas II yaitu lbuk Ariati untuk menjadi observer aktivitas guru (peneliti), teman sejawat yaitu Sri Sanita untuk menjadi observer aktivitas siswa. 


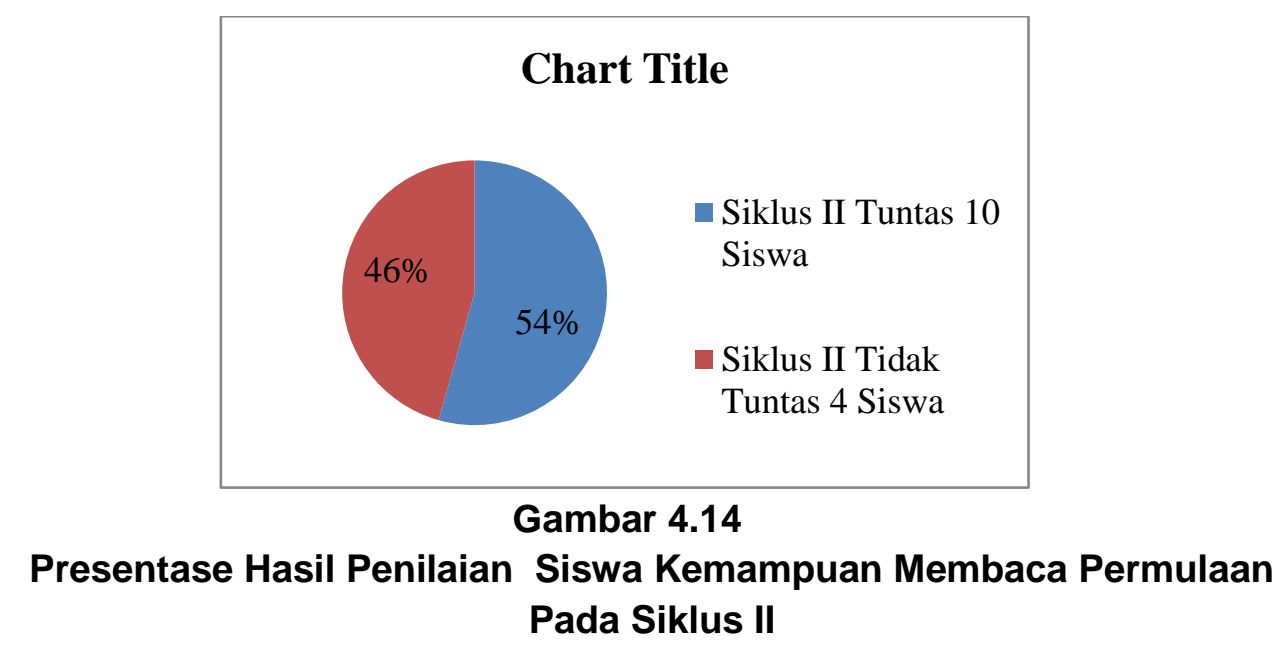

Hasil tes pada tindakan siklus II menghasilkan belajar siswa mengalami peningkatan menjadi 10 siswa atau 74,7\% dan 4 atau 63,25\% siswa yang belum tuntas belajar. Perolehan skor ratarata mengalami peningkatan sebesar 7,14. Hasil belajar siswa sudah memenuhi KKM. Setelah dilakukan tindakan siklus I dan siklus II dalam belajar membaca permulaan dengan menggunakan metode Struktur Analisis Sintesis proses belajar siswa sudah bisa dikatakan berhasil.

\section{KESIMPULAN}

Berdasarkan hasil penelitian dan pembahasan dapat disimpulkan bahwa metode struktur analisi sintesis sudah dilaksanakan dalam pembelajaran kemampuan membaca permulaan siswa kelas II SDN 016 Kemang Indah. Sebelum melaksanakan struktur analisi sintesis siswa diberi penjelasan mengenai hal-hal yang harus dijelaskan sebelum memulai kegiatan membaca permulaan. Siswa mendengar penjelasan guru tentang belajar membaca permulaan menggunakan metode struktur analisis sintesis, memberitahukan cara langkah-langkah metode struktur analisi sintesis serta aspek membaca permulaan. Siswa dibimbing menempelkan kartu kata metode struktur analisi sintesis ke papan fanel, selanjutnya dibimbing dalam membaca kata dan kalimat pada teks percakapan dengan aspek-aspek membaca dengan benar. Sesuai dengan alur cerita percakapan, serta memahami isi dari teks tersebut.

Pelaksanaan metode struktur analisi sintesis dalam pembelajaran kemampuan membaca permulaan siswa kelas II SDN 016 Kemang Indah telah memberikan dampak positif, yaitu terjadi peningkatan terhadap proses pembelajaran. Peningkatan proses dapat dilihat dari perbandingan kondisi proses pembelajaran antara tahap pratindakan, tindakan siklus I, dan tindakan siklus II. Pada tahap pratindakan, siswa tampak pasif dan tidak bergairah untuk mengikuti proses pembelajaran. Pada tindakan siklus I, siswa terlihat mulai tertanam rasa keingintahuanannya terhadap pelajaran yang sedang di pelajari. Keaktifan dan keantusias siswa sudah mulai terlihat, beberapa siswa sudah aktif dalam belajar serta tanpa ragu dalam tanya jawab dengan guru maupun bertanya sesuatu yang belum dipahami dengan jelas. Selanjutnya, pada siklus II siswa sudah aktif, belajar dengan semangat, serta lebih termotivasi setelah proses belajar mengajar menggunakan kartu kata metode struktur analisis 
sintesis. Dengan bantuan metode tersebut telah membawa dampak yang baik terhadap siswa kelas II SDN 016 Kemang Indah terjadi peningkatan. Peningkatan dapat dilihat dari perbandingan nilai rata-rata tes membaca permulaan siswa pratindakan, tindakan siklus I, dan tindakan siklus II. Nilai ratarata siswa meningkat sebesar 66,8 pada siklus I (kondisi awal 59,0 meningkat menjadi 66,8) dan sebesar 7,14 pada siklus II (kondisi siklus I 66,8 meningkat menjadi 7,14). Ketuntasan belajar siswa meningkat sebesar 7 siswa atau $7,27 \%$ pada tindakan siklus I (kondisi awal 4 siswa atau 7,025\% meningkat menjadi 7 siswa atau 7,27\%) dan sebesar 10 siswa atau 74,7\% pada siklus II (kondisi siklus I 7 siswa atau 7,27\% meningkat menjadi 10 siswa atau 74,7\%).

\section{DAFTAR PUSTAKA}

Abdurrahman, M.(2002).Pendidikan Bagi Anak Berkesulitan Belajar. Jakarta: Rineka Cipta.

Arikunto, Suharsimi. (2016). Prosedur Penelitian Suatu Pendekatan Praktik. Jakarta: Bumi Aksara.

Anwar, Mochamad.(2011). IImu Kebidanan. Jakarta:PT Bina Pustaka Sarwono Prawiroharjo.

Darwadi.(2002).Langkah-Langkah Keterampilan Proses. Jakarta:Gramedia.

Fadhilaturrahmi, F. (2017a). Penerapan Pendekatan Saintifik Untuk Meningkatkan Kemampuan Komunikasi Matematik Peserta Didik di Sekolah Dasar. EDUHUMANIORA: Jurnal Pendidikan Dasar, 9(2), 109118. https://doi.org/10/17509/EH.V912.7078

Marta, R. (2018). Penerapan Model Kooperatif tipe Nominal Group untuk Meningkatan Hasil Belajar Matematika di Kelas IV Sekolah Dasar. Jurnal Basicedu Volume 2 Nomor 1 Tahun 2018 Halaman 82.

Sanjaya,Wina.(2009).Strategi Pembelajaran Berorientasi Strandar Proses Pendidikan.Prenada:Jakarta.

Solchan,T.W., dkk.(2010).Pendidikan Bahasa Indonesia Di SD. Jakarta: Universitas Terbuka.

Sugiyono.(2007).Metode Penelitian Kuantitatif Dan R\&D.Bandung:Alfabeta.

Susanto, A.,(2011).Perkembangan Anak Usia Dini.Jakarta:Bumi Aksara.

Zuriah, Nurul.(2007). Pendidikan Moral Dan Budi Pekerti Dalam Perspektif Perubahan Mengagas Platform Pendidikan Budi Pekerti Secara Kontekstual Dan Futuristik. Jakarta: PT. Bumi Aksara. 